\title{
TALENT MANAGEMENT: A SYSTEMATIC REVIEW
}

\author{
Maha Lutfi Al- Dalahmeh \\ Károly Ihrig Doctoral School of Management and Business, University of Debrecen, \\ Debrecen, Hungary \\ Mahalutfi87@gmail.com
}

\begin{abstract}
Talent Management (TM) has become one of the important strategic topics for managers in global organizations and businesses in general. Despite the importance of talent management, researches in the area are still few, mainly conceptual research. The purpose of this article is to enhance the readers understanding of the domain of talent management concept perspectives, importance and the main practices. At the same time giving a general idea about the connection with other HRM functions, based on secondary data and researches in the areas of talent management. To achieve the aim of this article, the existing body of studies was reviewed, which were chosen based on the relevance to the talent management issue. Also, the articles which were published recently in this field were adopted.
\end{abstract}

Keywords: Human Resources Management, Attraction, Development, Workforce planning.

JEL Classification: 015

\section{Introduction}

In recent years the concept of talent management is distinguished as fairly new and it has attracted the interest of most of the researchers (Lewis and Heckman, 2006), so the organizations are required to distinguish between their employees according to their performances (Kontoghiorghes, 2016; Mensah, 2015). Human capital is the mixture of skills, experiences, knowledge, motivation, and capabilities of the employees. Because of that, it is important to recognize how to manage and control the talented employee, to invest in their skills, experience, knowledge and to enhance productivity and performance of organization (Burbach and Royle, 2010; Máté et al., 2016).

Most booming businesses recognized years ago that the most efficient practices of talent management are directly associated with the organizations culture and strategy (Gamama et al., 2018). In the current business environment, there is a high demand for talented employees in organizations (Cappelli, 2008). Although most of the organizations apply the practices of talent management there are a lot of mysterious issues that need to be cleared (Van Zyl et al., 2017).

The business environment has gone through many changes in different aspects such as the nature of work and the new forms of work (Bozionelos and Wang, 2006), which come from new knowledge innovation, new skills and increasing competition between firms (Garrow and Hirsh, 2008).

The organizations focused on their intangible assets like knowledge and talented employees because the business environment is characterized by uncertainty, complexity, and unpredictability (Chuai et al., 2008; Dajnoki and Héder, 2017). By keeping an eye on successful organizations one can observe that the organization which is hiring, managing and retaining high performed and talented employees have a high level of organizational success, which explains the increasing demand and competition for skilled employees on a global level (McDonnell et al., 2017). 
It's become obvious that the essential asset of a successful organization is human capital because it plays a fundamental role in the competitiveness and growth of the organization (Lockwood, 2006) that, put the human resources management on the front line and a strategic business partner in the organization (Collings et al., 2019). So as a result, human resources management (HRM) and human resources (HR) practices have become important, thus, they are trying to find a strong framework and develop the efficiency of their practices (Collings and Mellahi, 2009).

Based on the reviewed literature which was chosen based on the relevance to the talent management issue, the article concentrated on clarifying what is the main perspectives which define talent management, why it is important to adopt talent management and what is the most common applied practices. Due to that, a synopsis will be provided to readers about the best practices and how they are defined in literature.

\section{Literature Review}

\subsection{Talent management definitions}

Opinions differ about the definition of talent management, but it is recognized that the idea of the concept of talent management has appeared in the research published by Mckinsey studies "talent war" (Michaels et al., 2001). Then it was developed to be published as a book in 2001 (Nilsson and Ellström, 2012). So it is not a new concept as maintained before, but the researches are still few (Brbach and Royle, 2010) and recently it has become a vital part of business human resource strategies and has lately had a growing interest in the area of human resources management researches (Capelli, 2008).

On the other hand, there is no agreement about the definition of talent, and there are no specific and clear conceptual borders of talent management either (Collings and Mellahi, 2009). In the literature though, the concept in general is still not well-defined according to the process and decision alternatives (Gallardo et al., 2013). Though the idea emerges to be closely connected to concepts that include human resource management, workforce planning, and employability (Lewis and Heckman, 2006). Having reviewed the literature, there are three main perspectives of the definition of talent management (Lewis and Heckman, 2006):

In the first perspective of talent management it is considered as a set of function and practices which are the typical practices and functions of human resources management (Mucha, 2004). According to this perspective it is related to the same function of HRM practices such as planning, training, development and retaining (lles et al., 2010; Schiemann, 2014). For example, Creelman (2004) defines TM as a process of recruitment, development and maintaining talents which is close to the traditional definition of HRM.

The second perspective says that the organization is designing talent pools of employees who are called exclusive people, people who can make a vital change into the future and current performance of the firms (Rothwell, 2011). The firms can hunt these people through practices associated with workforce planning and development, thus the practices are related to employees (McCauley and Wakefield, 2006).

The third perspective assumed that talent management is related to specific positions which are called key positions in firms or Exclusive position (Anlesinya et al., 2019). This perspective is considered as an approach that begins with identifying crucial jobs for those positions that need highly performed and talented people (Tarique and Schuler, 2010; Sparrow et al., 2014).

According to Ready and Conger (2007), talent management is the process of planning human resources to meet up with the demands of the organization under the terms of employing talented personnel. To achieve that goal an effective reward system existence is obligatory (Ready and Conger, 2007). 
Maximizing profits is an essential aim for each organization all over the world along with minimizing the costs (Allen, 2004). From this point, we can consider TM as an important tool to minimize the cost of hiring new employees by keeping talented employees in the staff and improve their skills, hence, the talented employees turn out to be a core asset in any organization (Nalbantian and Guzzo, 2009).

TM in general, aims at workforce planning, attracting talented employees, developing these employees and retaining these employees (Rothwell, 2011).

Lewis and Heckman (2006) say that talent management has prospected from three different angles. The first one declares that TM is a human resources management department which makes all employees stand on the same side of the ship with no differences between them even when it comes to talents (Snell, 2007). The second one demands to build talented pools by means of securing current talented personnel and developing them (Creelman, 2004). The third one focuses on separate employees' performance where evaluation plans are set to identify and keep class $A$ and $B$ employees and expel grade $C$ employees (Rothwell, 2011).

Also, it is defined as "The sum of peoples" capabilities, experiences, competencies, attitudes, and behaviour that can be turned into organizational performance" by Pillay et al. (2008). Another definition of talent management is: "a new business science that blends workforce planning, acquisition, development, mobility, and measurement into a strategic discipline" (Stevens, 2008). Also, it is commonly agreed that talent management directly engages workforce planning, recruitment, human capital development, and diversity (lles et al., 2010).

Another definition is that talent management is about positive things, doing things for your best people, investing in developing them, building their potential and assisting people to make the best use of their strengths (Garrow and Hirsh, 2008).

Based on previous efforts afforded in defining talent management, a certain definition for talent management is concluded like this: it is an integrated process that contains several specified procedures that contribute overwhelmingly in the success of the organization and these procedures are workforce planning, talented employee's acquirement, developing and training these talented employees, and sustaining them as assets of the organization (Iles et al., 2010).

\subsection{The Importance of Talent Management}

Since a competitive advantage is essential for any organization (Gelens et al.,2013), and according to the fact that talented employees are considered as an essential asset of any organization ( $\mathrm{Li}$ and Devos, 2008), the need for talented employees rises because of the contribution of their knowledge and experience on the performance of the organization (Schuler et al., 2011). Moreover, an organization`s performance directly affects business result which affects the profit and productivity of that organization (Hills, 2009).

Retaining talented employees will affect the organization from various aspects, these aspects may include the costs of recruiting talented employees, in addition to the time, effort, and costs needed to develop these talents according to the needs of the organization. (Rothwell, 2011). Also, either in the cases of uncertainty or the cases of flourishing, the need for talented employees arises from the depths of the ocean of failure (Brown and Tannock, 2009).

The importance also comes from the definition where Talent management is defined as a systematic attraction, identification, development, engagement, retention, and deployment of those individuals who possess a high potential that creates a particular value to an organization (Krishnan and Scullion, 2017).

Talent management plays a key role in affecting the entire organization (Stevens, 2008). Talent management has a great impact on the performance of the organization by 
minimizing the costs of the hiring process (Boon et al.,2011); it also increases the productivity of the firm in addition to the profitability and output (Collings and Mellahi, 2009). When the organization is applying TM, it creates tremendous opportunities for competitive advantages (Schuler et al., 2011). Also, the organization's position in its industry is determined by its ability to retain, engage, and develop talents which turned TM into a factor of failure or success for an organization (Luna-Arocas and Morley, 2015).

\subsection{Talent Management practices}

As mentioned previously, talent management shares several similarities with human resources management, moreover, they share some of the same practices that are applied in both departments that eventually lead to the success of the organization (Schuler et al., 2011). Organizational talents nowadays require management and improvements due to the uncertainty of environments such as enduring skills shortages and employee demands for work-life balance (Lewis and Heckman, 2006). Mastery of management appears in the organizations' abilities to enhance strategies, policies, and programs for attracting, developing, and retaining talented employees (Snell, 2007).

That can be achieved by determining what the organization needs of either current capabilities or envisioned talents required (Ready, 2007). To apply talent management professionally, the human resources department needs the assistance of the top management of that organization to be highly effective and fruitful starting from workforce planning until talent retention and passing attracting talented employees and developing them (Cappelli, 2008; Shrimali and Gidwani,2012).

\subsubsection{Talented workforce planning}

In business, it is often stated that the highest value of an organisation is provided by the employees working there (Héder et al., 2018). According to workforce planning, it must be comprehended by the managers that their HR tasks and the process of attracting, recruiting, developing and retaining efforts are directly connected to the main goals of the organization (Creelman, 2004), which leads managers to afford extra effort to achieve their duties upon realizing the importance of their role for the sake of the whole organization's excellence (Schweyer, 2010). The roles of talented workforce planning conclude envisioning future business and environmental demands to meet with the HR requirements obliged by these circumstances (Creelman, 2004).

The Activities of talented Workforce Planning (Schweyer, 2010):

- Talent Inventory: this includes the current talents operating in the organization and their roles.

- Workforce Forecast: this anticipates the potential needs for talents.

- Action Plans: the procedures from the moment an employee is hired until the stage of compensation.

- Control and Evaluation: it allows the HR department to monitor the process of workforce planning using closed-loop feedback.

To conclude, talented workforce-planning aims at allocating specific employees with specific talents to specified jobs at the correct time with the convenient skills required to fulfill these jobs (Dries, 2013). So, talent management is how the organization implements its strategic workforce plan. It is also the mechanism by which the organization adjusts its talent supply, based on changing business needs and the organization needs as well (Morgan and Jardin, 2010). Furthermore, it is considered as one of the analytic, forecasting, and planning procedures (Sheehan and Anderson, 2015), that is connected to talent management activities to ensure an organization has the right people in the right places at the right time and at the right price to implement its business strategy (Tucker et al., 2005). 


\subsubsection{Talent Attraction}

One of the most important practices of talent management is to attract talented employees and mastering that practice (Pruis, 2011). The study of Shrimali and Giwani (2012) states that the reputation of an organization is an important factor in attracting key employees. The study of Lyria et al. (2017) clarified the factors (monetary and non-monetary) which made people get attracted to a certain organization. These factors affected individuals ' choices concerning the work opportunity in an organization and the selection of an organization, as well (Jenkins, 2009).

Factors like work-life balance, competitive payment, and challenging work are some of the significant factors to attract employees (Pruis, 2011). Organizations should follow specific procedures to attract talented employees (Lockwood, 2006), through establishing a clear strategy to attract talented employees from outside the organization and improve the skills of the other talented employees inside the organization (Chuai et al., 2008).

Talent attraction also depends on the branding of how organization is represented in the market, i.e. people are excited about working for the organization and companies can be selective in the approach culture of the organization (Moczydłowska, 2012). According to Collings and Mellahi (2009), all talented employees in different sectors are looking for an organization that offers exciting challenges, great development opportunities and meaningful work in a successful organization, where great leaders can lead them (Csordás, 2020). Whilst substantial payment is a significant attractor, talented individuals appear more attracted by the prospect of meaningful work in an open, trusting and performance-oriented culture, rather than by salary alone (Lewis and Heckman, 2006; Dajnoki and Kun, 2016).

The quality of an organization is the quality of the workforce it possesses. The best way to have talent at the top is to have talent at the bottom; their development needs career inspirations, strengths and weaknesses, abilities, likes and dislikes. It is easier, therefore, to determine what motivates whom and this helps a lot in the job enrichment process (Iles et al., 2010; Héder and Dajnoki, 2017a).

\subsubsection{Talent Development}

According to Hills (2009), it was assumed that there would have been five retirees for every new employee; therefore, organizations can get ahead of the lack of talents by empowering and encouraging their current talents (Héder and Dajnoki, 2017b). Talent development can go through several stages, such as developing subordinates, managers, and certification. Each organization in the world has its own talent development policy (Cheloha and Swain, 2005), because there are no common standards which should be applied in all organizations (Lehmann, 2009). There are some mutual concepts on how to deal with employees that exceed the expectations in performance which allows the company to have a long-term vision to change its recruiting policy from "hiring people to fill up chairs" to "hiring people and developing them to serve future opportunities and needs" (Gandz, 2006).

According to Pruis (2011), a company would hire highly qualified and talented employees that were not needed at the moment they were hired (Lockwood and Nancy, 2006), but they had the potential for imminent strategic demands or that they had required future skills which will grant the company the advantage of acquiring a variety of talents (Khilji et al., 2015). On the other hand, these organizations would not keep in mind the factor, which can cause mediocre performance amongst the other employees (Schweyer, 2010).

Moreover, organizations in general do not hire professional and talented employees only, they also hire employees that are below the level (Chuai et al., 2008). Besides, these highly qualified and talented employees will have to be standardized according to the standards of the organization (Pillay et al., 2008). One of the main purposes of talent management is to classify employees in categories according to their skills (Thomas,2009), to determine who are highly qualified and who are the poor performers (Hills, 2009). Upon identifying poor performers, the talent management process must be able to take actions to specify whether 
the employee is unskilled which will urge the need to train him (McDonnel et al.,2017), or that poor performers will be identified and then moved to other positions where they would show their inner skills (Blass, 2007).

\section{Conclusions}

By looking at the high level of interest in the concept of talent management over recent years, it is somewhat unacceptable that it stays relatively not well-defined and lacks the theoretical framework. This paper is based on the current body of the literature finds from a theoretical point of view. The area of talent management is in its initial phase and a significant level of theoretical development is needed.

The contribution of this paper is two-folded; to develop a clear and short definition of talent management from different perspectives as mentioned above. The first perspective defined it as typical practices and functions of human resources management. However, the second one assumed to design talent pools for exclusive employees, who could make a vital change in the whole performance. Finally, the last perspective focuses on the key positions which need highly talented employees. Thus, practitioners and managers could have a better chance to understand by which perspective they could define talent management, and how they could use it to improve performance.

In addition, practitioners and managers have the potential to determine, according to the three main practices mentioned in this paper, which one is more proper to be applied and has a direct effect on employees' performance and loyalty, as well. By applying that managers can develop and improve the strategy of the firm.

Aforementioned, talent management has a strong effect on maintaining employees and performance, thus managers should pay attention to have systematic programs for developing and training talented employees. To convert their implicit knowledge and skills to explicit knowledge, which could be shared with all the staff.

This is generally accepted in the reviewed literature, from which we can draw the conclusion that the importance of talent management lies in helping the firm to reduce the cost of hiring new employees through retaining talented employees and developing them by specific training programs

Hoping that the proposed framework provides a foundation for future researches that seek to deepen the effects of implementing talent management practices.

\section{Acknowledgement}

The publication is supported by the EU-funded Hungarian grant EFOP-3.6.3.-VEKOP-16-2017-00007, for the project entitled "From Talent to Young Researchers" - Supporting the Career-developing Activities of Researchers in Higher Education.

\section{References}

Allen, D.G., Shore, L.M. and Griffeth, R.W., 2003. The role of perceived organizational support and supportive human resource practices in the turnover process. Journal of management, 29 (1), pp. 99-118.

Anlesinya, A., Dartey-Baah, K., and Amponsah-Tawiah, K., 2019. Strategic talent management scholarship: a review of current foci and future directions. Industrial and Commercial Training, 51 (5), pp. 299-314.

Blass, E., 2007. Talent Management: Maximising talent for business performance: Executive Summary. Chartered Management Institute. 
Boon, C., Den Hartog, D.N., Boselie, P. and Paauwe, J., 2011. The relationship between perceptions of HR practices and employee outcomes: examining the role of personorganisation and person-job fit. The International Journal of Human Resource Management, 22 (1), pp.138-162.

Bozionelos, N. and Wang, L., 2006. The relationship of mentoring and network resources with career success in the Chinese organizational environment. The International Journal of Human Resource Management, 17 (9), pp. 1531-1546.

Brbach, R. and Royle, T., 2010. Talent on demand? Talent management in the German and Irish subsidiaries of a US multinational corporation. Personnel Review, 39(4), pp.414-431.

Brown, P. and Tannock, S., 2009. Education, meritocracy and the global war for talent. Journal of Education Policy, 24 (4), pp. 377-392.

Cappelli, P., 2008. Talent management for the twenty-first century. Harvard business review, 86 (3), pp. 74-81.

Cheloha, R. and Swain, J., 2005. Talent management system key to effective succession planning. Canadian HR Reporter, 18 (17), pp.5-7

Chuai, X., Preece, D. and lles, P., 2008. Is talent management just "old wine in new bottles"? The case of multinational companies in Beijing. Management Research News, 31 (12), pp. 901-911.

Collings, D.G. and Mellahi, K., 2009. Strategic talent management: A review and research agenda. Human resource management review, 19 (4), pp. 304-313.

Collings, D.G., Mellahi, K. and Cascio, W.F., 2019. Global talent management and performance in multinational enterprises: A multilevel perspective. Journal of Management, 45 (2), pp. 540-566.

Creelman, D., 2004. Return on investment in talent management: Measures you can put to work right now. Human Capital Institute, 2121.

Csordás, A., 2020. Diversifying Effect of Digital Competence. AGRIS on-line Papers in Economics and Informatics, 12 (1), pp. 3-13.

Dajnoki, K., Kun, A.I. 2016. Frissdiplomások foglalkoztatásának jellemzői az agrárgazdaságban. Gazdálkodás 60. évf.: IV. szám pp. 289-304.

Dajnoki, K., Héder, M., 2017. „Új szelek fújnak” - a HR válasza a globalizáció és a változás kihívásaira. Hadtudomány, 27(E-issue), pp. 84-93. DOI 10.17047/HAD TUD.2017.27. E.8.

Dries, N., 2013. Talent management, from phenomenon to theory. Human Resource Management Review, 23 (4), pp. 267-271.

Gallardo-Gallardo, E., Dries, N., and González-Cruz, T.F., 2013. What is the meaning of 'talent'in the world of work? Human Resource Management Review, 23(4), pp.290-300.

Gamama, Y., Bazza, M.I. and Imam, Y.B.K., 2018. Talent Management and Organisational Performance in Public Sector: A Review. Journal of Management Sciences, 18 (1), pp. 56-65.

Gandz, J., 2006. Talent development: the architecture of a talent pipeline that works. Ivey Business Journal, 70 (3), pp.1-4.

Garrow, V. and Hirsh, W., 2008. Talent management: Issues of focus and fit. Public Personnel Management, 37(4), pp. 389-402.

Gelens, J., Dries, N., Hofmans, J. and Pepermans, R., 2013. The role of perceived organizational justice in shaping the outcomes of talent management: A research agenda. Human Resource Management Review, 23 (4), pp. 341-353.

Héder, M., Dajnoki, K., 2017. The Characteristics of International and Hungarian Talent Shortage. Annals of The University of Oradea Economic Science,1 (1st Issue) pp. 621-636. Héder, M., Dajnoki, K., 2017a. Connection of Talent and Career Management - Differences and Similarities. Network Intelligence Studies, 5 (I 9), pp. 57-66.

Héder, M., Szabó, Sz., Dajnoki, K., 2018. Effect of Labour Market Changes on HR Functions. Anali Ekonomski Fakulteta U Subotici / The Annals of The Faculty of Economics Subotica, 54 (39/2018) pp. 123-138. 
Hills, A., 2009. Succession planning-or smart talent management? Industrial and commercial Training, 41 (1), pp.3-8.

Iles, P., Chuai, X. and Preece, D., 2010. Talent management and HRM in multinational companies in Beijing: Definitions, differences and drivers. Journal of World Business, 45 (2), pp.179-189.

Jenkins, A.K., 2009. Keeping the talent: Understanding the needs of engineers and scientists in the defense acquisition workforce. Defense AR Journal, 16 (1), pp. 164-170.

Khilji, S.E., Tarique, I. and Schuler, R.S., 2015. Incorporating the macro view in global talent management. Human Resource Management Review, 25 (3), pp. 236-248.

Kontoghiorghes, C., 2016. Linking high performance organizational culture and talent management: satisfaction/motivation and organizational commitment as mediators. The International Journal of Human Resource Management, 27 (16), pp. 1833-1853.

Krishnan, T.N. and Scullion, H., 2017. Talent management and dynamic view of talent in small and medium enterprises. Human Resource Management Review, 27(3), pp.431-441. Lehmann, S., 2009. Motivating talents in Thai and Malaysian service firms. Human Resource Development International, 12 (2), pp. 155-169.

Lewis, R.E. and Heckman, R.J., 2006. Talent management: A critical review. Human resource management review, 16 (2), pp. 139-154.

Li, F.F, and Devos, P., 2008. Talent management: art or science? The invisible mechanism between talent and talent factory. Journal of World Business, 47 (2), pp. 159-179.

Lockwood, N.R., 2006. Talent management: Driver for organizational success. HR Magazine, 51 (6), pp. 1-11.

Luna-Arocas, R. and Morley, M.J., 2015. Talent management, talent mindset competency and job performance: the mediating role of job satisfaction. European Journal of International Management, 9 (1), pp.28-51.

Lyria, R. K., Namusonge, G. S., \& Karanja, K. (2017). Role of Talent Management on Organisation Performance in Companies Listed in Nairobi Securities Exchange in Kenya. Journal of Human Resource and Leadership, 1 (3), pp. 1-17.

Máté, D., Darabos, É., Dajnoki, K. 2016. The Impact of Human Capital on Labour Productivity Regarding the ET-2020 Targets. Network Intelligence Studies IV(1) pp. 61-67.

McCauley, C. and Wakefield, M., 2006. Talent management in the 21st century: Help your company find, develop, and keep its strongest workers. The Journal for Quality and Participation, 29 (4), pp. 4-10.

McDonnell, A., Collings, D.G., Mellahi, K. and Schuler, R., 2017. Talent management: a systematic review and future prospects. European Journal of International Management, 11 (1), pp. 86-128.

Mensah, J.K., 2015. A "coalesced framework" of talent management and employee performance: For further research and practice. International Journal of Productivity and Performance Management, 64 (4), pp. 544-566.

Michaels, E., Handfield-Jones, H. and Axelrod, B., 2001. The war for talent. $1^{\text {st }}$ Ed., London: Harvard Business Press

Morgan, H. and Jardin, D., 2010. Integrated talent management. OD PRACTITIONER, 42(4), pp.24-35.

Mucha, R.T., 2004. The Art and Science of Talent Management. Organization Development Journal, 22 (4), pp. 96-100.

Nalbantian, H.R. and Guzzo, R.A., 2009. Making mobility matter. Harvard Business Review, 87 (3), pp.76-84.

Nilsson, S. and Ellström, P.E., 2012. Employability and talent management: challenges for HRD practices. European Journal of Training and Development, 36 (1), pp.26-45.

Pillay, P., Subban, M., and Qwabe, B, 2008. Talent management. Journal of Public Administration, 43 (Special issue 1), pp. 308-323. 
Pruis, E., 2011. The five key principles for talent development. Industrial and Commercial Training, 43 (4), pp.206-216.

Ready, D.A. and Conger, J.A., 2007. Make your company a talent factory. Harvard Business Review, 85 (6), pp. 68.

Rothwell, W.J., 2011. Replacement planning: A starting point for succession planning and talent management. International Journal of Training and Development, 15 (1), pp. 87-99.

Schiemann, W.A., 2014. From talent management to talent optimization. Journal of World Business, 49 (2), pp. 281-288.

Schuler, R.S., Jackson, S.E. and Tarique, I., 2011. Global talent management and global talent challenges: Strategic opportunities for IHRM. Journal of World Business, 46 (4), pp. 506-516.

Schweyer, A., 2010. Talent management systems: Best practices in technology solutions for recruitment, retention and workforce planning. $1^{\text {st }}$ Ed., London: John Wiley \& Sons.

Sheehan, M. and Anderson, V., 2015. Talent management and organizational diversity: A call for research. Human Resource Development Quarterly, 26 (4), pp.349-358.

Shrimali, H., and Gidwani, B. 2012. Role of talent management in sustainable competitive advantage: Rising to meet business challenge. Pacific Business Review International, 4 (3), pp. 29-33.

Snell, A., 2007. Strategic talent management, Human Resource Management: The relationship of mentoring and network resources with career success in the Chinese organizational environment, Int. J. of Human Resource Management, 17 (9), pp. 15311546.

Sparrow, P., Scullion, H. and Tarique, I., 2014. Multiple lenses on talent management: Definitions and contours of the field. Contemporary issues in International Context, Cambridge University Press.

Stevens, H.P., 2008. Total quality management now applies to managing talent. The Journal for Quality and Participation, 31 (2), pp.15-22.

Tarique, I. and Schuler, R.S., 2010. Global talent management: Literature review, integrative framework, and suggestions for further research. Journal of World Business, 45 (2), pp.122-133.

Thomas, K., 2009. Talent strategies for innovation. Economist Intelligence Unit Supported by the Government of Ontario, September, pp.1-10.

Tucker, E., Kao, T. and Verma, N., 2005. Next-generation talent management. Business Credit, 107, pp. 20-27.

Van Zyl, E.S., Mathafena, R.B. and Ras, J., 2017. The development of a talent management framework for the private sector. SA Journal of Human Resource Management, 15 (1), pp. $1-19$.

\section{Bio-note}

Dalahmeh Maha, is a PhD student in Károly Ihrig Doctoral School of Management and Business University of Debrecen. Her main research interests refer to talent management and organisational behaviour. 